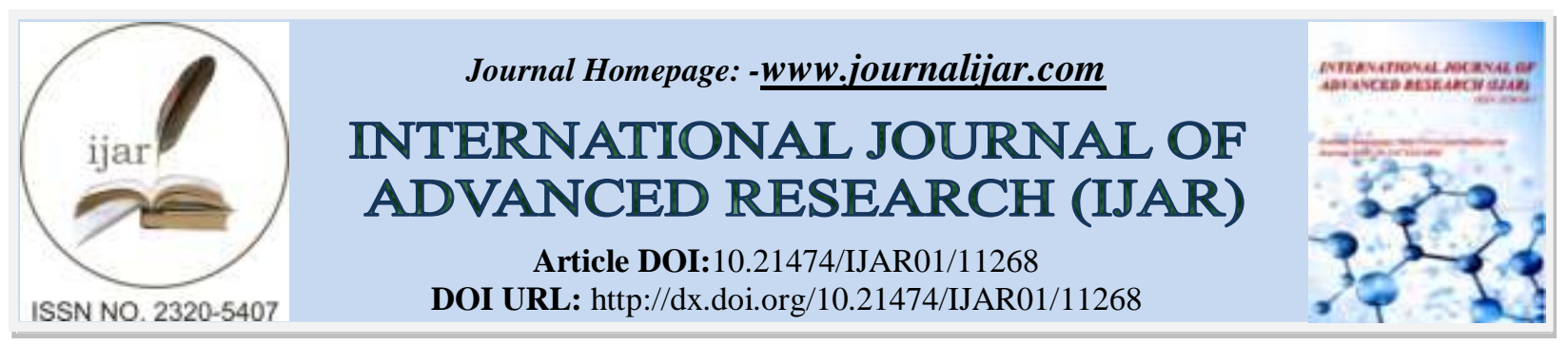

\title{
RESEARCH ARTICLE \\ OPTIMUM BASETHICKNESS DETERMINATION OF A BACKILLUMINATED SILICON SOLAR CELL: IRRADIATION EFFECT
}

\author{
Amadou Sarr Gning, Mamadou Lamine Ba, Mamour Amadou Ba, Gora Diop, Ibrahima Diatta, El Hadji \\ Sow, Oulimata Mballo and Gregoire Sissoko \\ Laboratory of Semiconductors and Solar Energy, Physics Department, Faculty of Science and Technology, \\ University Cheikh Anta Diop, Dakar, Senegal.
}

\section{Manuscript Info}

Manuscript History

Received: 05 May 2020

Final Accepted: 10 June 2020

Published: July 2020

\section{Key words:-}

Bifacial Silicon Solar Cell, Irradiation, Recombination Velocity, Base Thickness.

\section{Abstract}

In this paper, we propose a method to determine the optimum thickness of a bifacial silicon solar cell back illuminated and under irradiation. The expressions of back surface recombination velocity of excess minority carrier depending on both irradiation energy $(\phi p)$ and damage coefficient (kl) are established. From their plots, base optimum thickness is deduced, and its relationships with bothirradiation energy $(\phi \mathrm{p})$ and damage coefficient (kl) are modeled.

Copy Right, IJAR, 2020,. All rights reserved.

\section{Introduction:-}

The damage imposed on a solar cell, by the irradiation flux of charged particles $(\phi p)$, in certain experimental laboratory conditions or in space, is modeled through the expressions of diffusion coefficient or lifetime [1] of the excessminority carriersin the semiconductor material.

Our study concerns the silicon solar cell $\left(\mathrm{n}^{+} / \mathrm{p} / \mathrm{p}^{+}\right)$previously subjected to various doses of radiation and illuminated by the back side with polychromatic light [2].

The density of the excess minority carrier is obtained by solving the diffusion equation in the base (p) of the solar cell, provided with the boundary conditions at the junction surface $(\mathrm{p}+\mathrm{p})$ and on the back surface $(\mathrm{p}+)$. These boundary conditions bring to the excess minority carriersrecombinationvelocity, respectively (Sf) at the junction and $(\mathrm{Sb})$ on the rear [3] [4] [5] [6].

The photocurrent is calculated and obtained as a function of these recombination velocities ( $\mathrm{Sf}, \mathrm{Sb}$ ) and the parameters $(\phi p, k l)$ of the irradiation imposed on the solar cell of $(\mathrm{H})$ thick base.

The study of the photocurrent as a function of the $(\mathrm{Sf})$ recombination velocity at the junction, for each irradiation parameter yields to extract the expressions of the $(\mathrm{Sb})$ recombination velocity on the rear face [7]. The analysis of these recombination velocityexpressions through their graphic representations as a function of the solar cell thickness $(\mathrm{H})[8]$ yields to obtain the optimum thickness under each irradiation parameter and mathematically modeled.

Corresponding Author:- Grégoire Sissoko

Address:- Laboratory of Semiconductors and Solar Energy, Physics Department, Faculty of Science and Technology, University Cheikh Anta Diop, Dakar, Senegal. 


\section{Theory:}

Minority carrier density:

Figure 1 shows an $(n+/ p / p+)$ silicon solar cell[5],[9], [10],back surface illuminated[11], [12](double side surface field) with polychromatic light and submitted to irradiation[13] [14] [15].

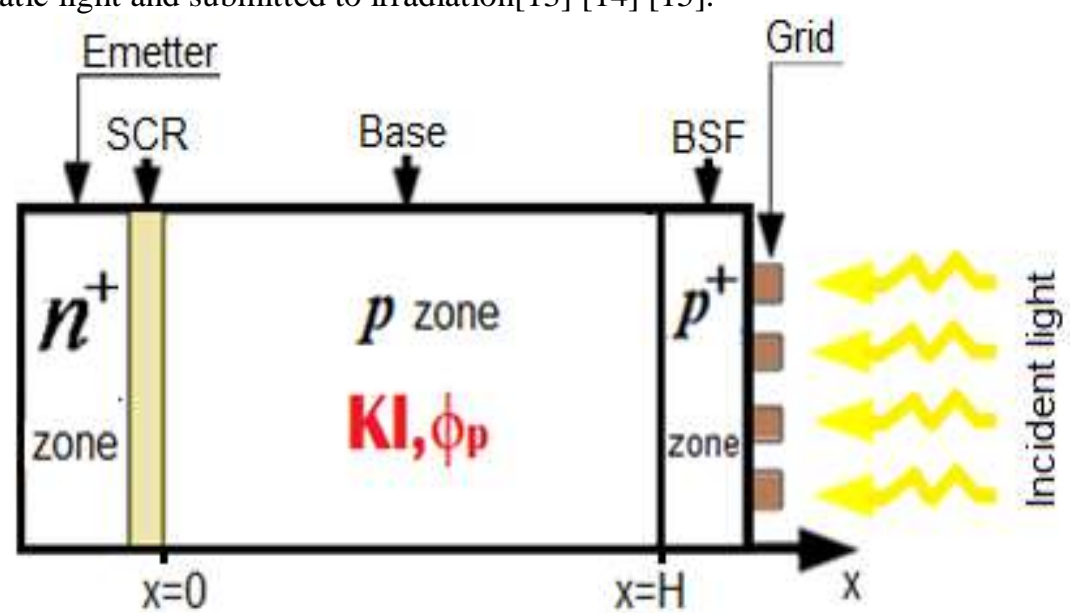

Figure 1:- $\mathrm{n}^{+}-\mathrm{p}-\mathrm{p}^{+}$solar cell back surfaceilluminated withpolychromatic ligth and under irradiation.

The continuity equation governing the excess minority carrier'sphenomena i.e. diffusion in the bulk and surfaces recombination, is defined by the following expression:

$$
D\left(k l, \phi_{p}\right) \frac{\partial^{2} \delta_{a r}\left(x, k l, \phi_{p}\right)}{\partial x^{2}}-\frac{\delta_{a r}\left(x, k l, \phi_{p}\right)}{\tau}+G_{a r}(x)=0
$$

D represents the excess minority carrier diffusion. When the material is submitted to the external conditions, it becomes effective diffusion coefficient and it is then dependent of parameters such as, magnetic field[16], temperature[17], frequency[18] [19]. Intrinsic parameters as doping rate [5]also influence the diffusion coefficient as well asgrain sizes and grain recombination velocity [20] [21] [22] [23].

The well-known Einstein's relation links the diffusion coefficient $\mathrm{D}(\mathrm{Kl}, \phi \mathrm{p})[24]$ [25]to the lifetime $(\tau)$ and the diffusion length $(\mathrm{L})$, for given irradiation $\phi \mathrm{p}$ and intensity $\mathrm{kl}$.

$$
\begin{aligned}
& D\left(k l, \phi_{p}\right)=\frac{L^{2}\left(k l, \phi_{p}\right)}{\tau} \\
& L(k l, \phi)=\frac{1}{\left(\frac{1}{L_{0}^{2}}+k l \cdot \phi\right)^{1 / 2}}
\end{aligned}
$$

$D(k l, \phi p)$ : is the diffusion coefficient of the electrons in the base under irradiation.

$L(k l, \phi p)$ : is the diffusion length of the excessminority carrier in the base as a function of the irradiation energy and the damage coefficient.

$\delta(x, k l, \phi p)$ : represents the density of excess minority carrier in the base resulting from polychromatic illumination and under the influence of irradiation.

$G_{a r}(x)$ is therate of generation of excess minority carrier at depth $\mathrm{x}$ in the base under polychromatic illumination. Its expression is given by[26]:

$$
G_{a r}(x)=n \times \sum_{i=1}^{3} a_{i} \times e^{-b_{i} \cdot(H-x)}(4)
$$


$\mathrm{x}:$ is the depth in the base of the solar cell.

$\delta(x, k l, \phi p)$ is determined from the resolution of equation (1) and is given in the following form:

$\delta_{a r}\left(x, k l, \phi_{p}\right)=A_{a r} \times \operatorname{ch}\left[\frac{x}{L\left(k l, \phi_{p}\right)}\right]+B_{a r} \times \operatorname{sh}\left[\frac{x}{L\left(k l, \phi_{p}\right)}\right]+\sum_{i=1}^{3} K_{i} \times e^{-b_{i} \cdot(H-x)}$

With $K_{i}=\frac{n \times\left[L\left(k l, \phi_{p}\right)\right]^{2} \times a_{i}}{D\left(k l, \phi_{p}\right) \times\left[b_{i}^{2} \times L^{2}\left(k l, \phi_{p}\right)-1\right]}$

The $\mathrm{A}_{\mathrm{ar}}$ and $\mathrm{B}_{\mathrm{ar}}$ coefficients are determined from the boundary conditions:

At the junction $(\mathbf{x}=\mathbf{0})$ :

$$
\left.D\left(k l, \phi_{p}\right) \frac{\partial \delta_{a r}\left(x, k l, \phi_{p}\right)}{\partial x}\right|_{x=0}=S_{f} \times \delta_{a r}\left(0, k l, \phi_{p}\right)_{(7)}
$$

Sf: is the excess minoritycarrier'srecombination velocity at the junction. It characterizes the operating point of the solar cell varying from short-circuit to open circuit [3] [4] [23].

Atthe rear face $(\mathrm{x}=\mathrm{H})$ :

$$
\left.D\left(k l, \phi_{p}\right) \frac{\partial \delta_{a r}\left(x, k l, \phi_{p}\right)}{\partial x}\right|_{x=H}=-S_{b}(k l, \phi p) \times \delta_{a r}\left(H, k l, \phi_{p}\right)
$$

$\mathrm{Sb}$ is the back surface recombination velocity of excess minority carrier[3],[25],[27],[28] resulting from the electric field created by the $\left(\mathrm{p} / \mathrm{p}^{+}\right)$high-lowjunction [11]. It characterizes the behavior of the excess minority carrierat the base back surface.

\section{Results And Discussions:-}

Influence of the irradiation on photocurrent density:

The photocurrent density is given by the following expression:

$$
J p h_{a r}(S f, k l, \phi p)=q \times D(k l, \phi p) \times\left[\frac{B_{a r}}{L(k l, \phi p)}+\sum_{i=1}^{3} k_{i} \times b_{i} \times e^{-b_{i} \times H}\right]
$$

Figures $\mathbf{2}$ and $\mathbf{3}$ show the profiles of the photocurrent density as a function of the recombination velocity at the junction(Sf) for different energy flows and for different damage coefficients. Figure 4 represents the profile of the photocurrent density as a function of the recombination velocity at the junction for different thickness of the base values. 


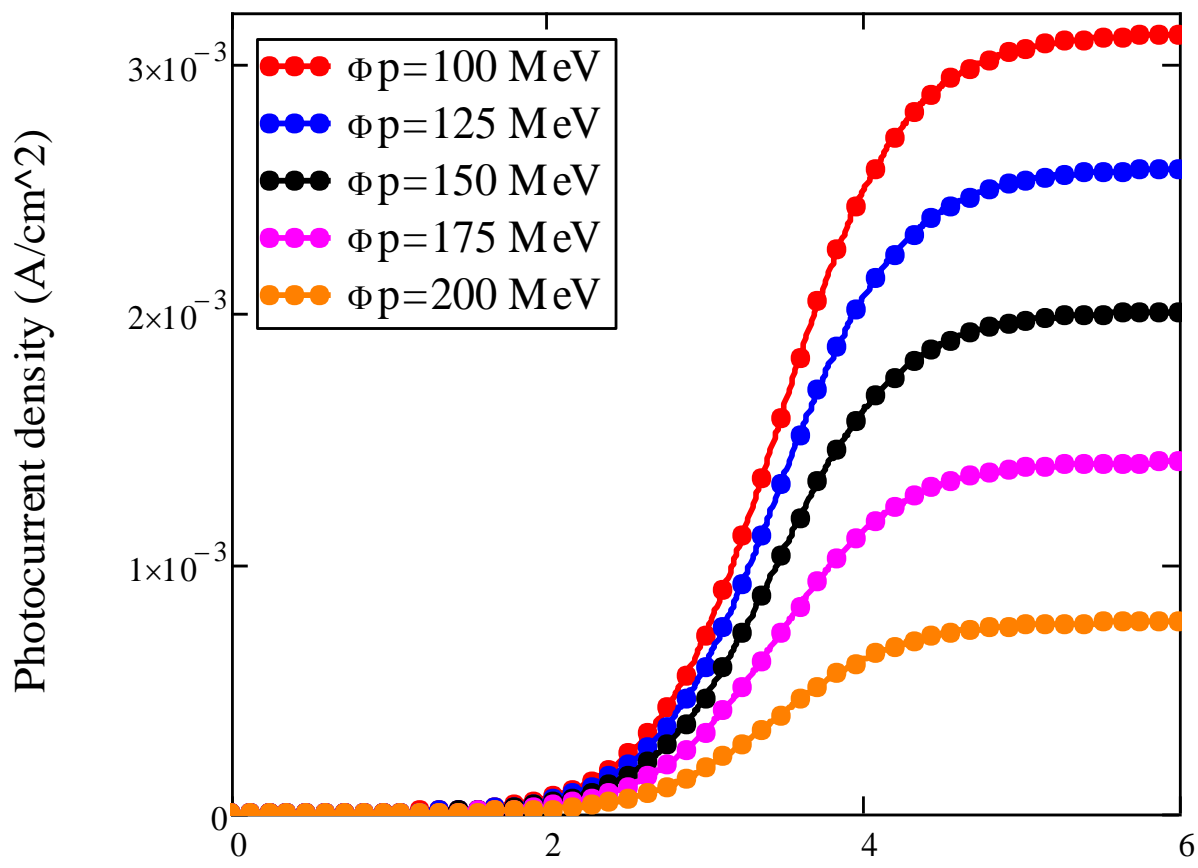

Junction recombination velocity $\mathrm{Sf}(\mathrm{cm} / \mathrm{s}) \times 10^{\wedge} 6$

Figure 2:- Photocurrent density as a function of the junction recombination velocity for different energy flows with $\mathrm{kl}=6 \mathrm{~cm}^{-2} / \mathrm{MeV}, \mathrm{H}=170 \mu \mathrm{m}$.

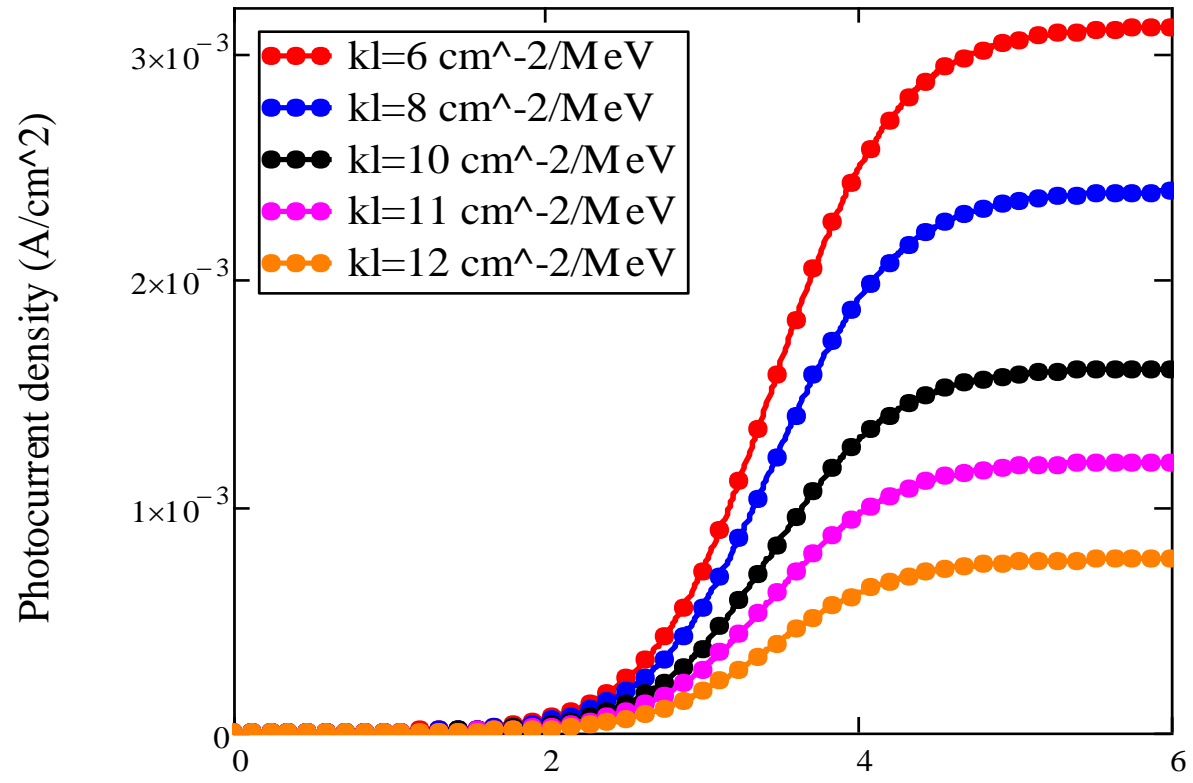

Junction recombination velocity $\mathrm{Sf}(\mathrm{cm} / \mathrm{s}) \times 10^{\wedge} 6$

Figure 3:- Photocurrent density as a function of the junction recombination velocity for different damage coefficientwith $\phi \mathrm{p}=100 \mathrm{MeV}, \mathrm{H}=170 \mu \mathrm{m}$. 


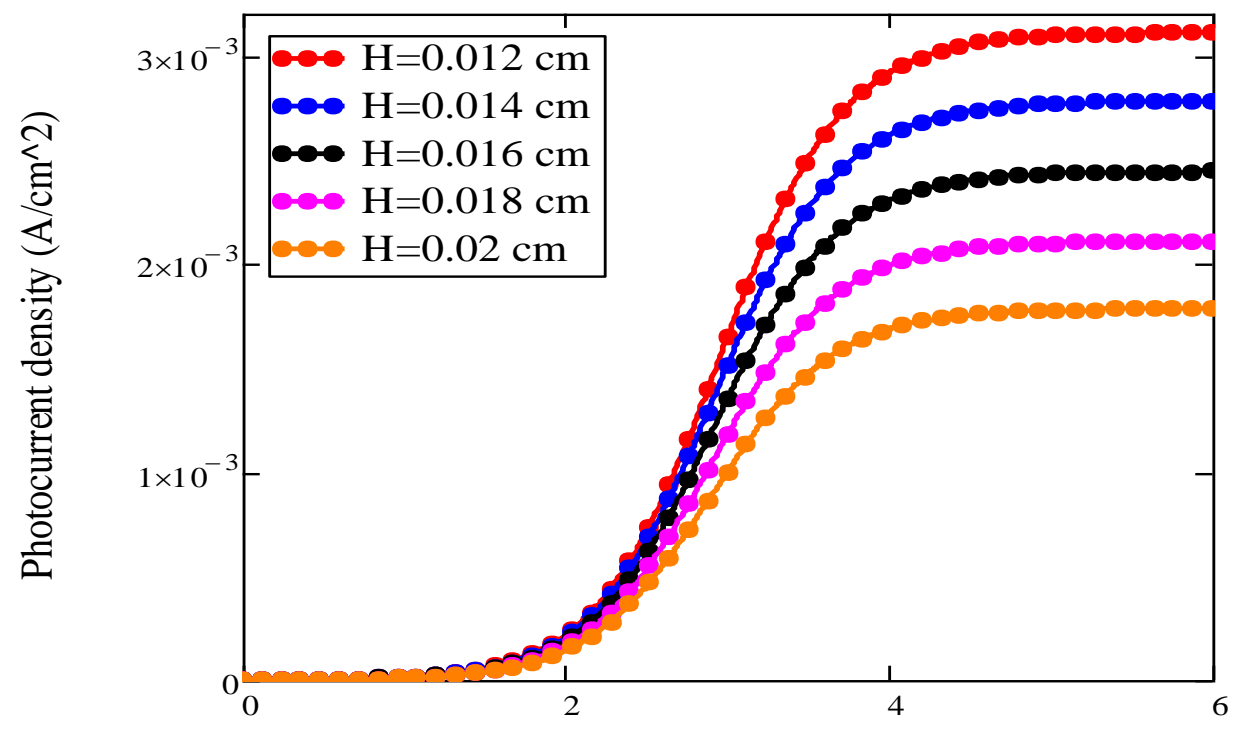

Junction recombination velocity $\mathrm{Sf}(\mathrm{cm} / \mathrm{s}) \times 10^{\wedge} 6$

Figure 4:- Photocurrent density as a function of the junction recombination velocity for different base thicknesswith $\phi \mathrm{p}=100 \mathrm{MeV}, \mathrm{kl}=6 \mathrm{~cm}^{-2} / \mathrm{MeV}$.

At Low Sf value, the solar cell operates under open circuit condition. It is indicated on all the figures $(2,3,4)$ that the photocurrent remained zero. Then when Sf increases, the photocurrent increases until reaching a plateau, which corresponds to the short circuit currentregardless of the flow of irradiation, its intensity or the thickness of the base. The short circuit current increases with both the intensity of irradiation and the base thickness and decreases with the irradiation flux.

The expression of $\mathrm{Sb}$ is then deduced by deriving equation (9) of the photocurrent density whatever (fp, $\mathrm{kl}$, and $\mathrm{H}$ ) with respect to Sf and at large Sf ranges [3] [4].

$$
\left[\frac{\partial \operatorname{Jph}\left(S f, k l, \phi_{p}\right)}{\partial S f}\right]_{S f \phi 4 \times 10^{4}}=0
$$

The resolution of this equation (10) thus gives respectively two expressions of the back surface recombination velocity as:

$$
\begin{aligned}
& \operatorname{Sb1}\left(H, k l, \phi_{p}\right)=-\frac{D\left(k l, \phi_{p}\right)}{L\left(k l, \phi_{p}\right)} \times \tanh \left(\frac{H}{L\left(k l, \phi_{p}\right)}\right)(11) \\
& \operatorname{Sb} 2(H, k l, \phi p)=\frac{D(k l, \phi p) \times\left[b_{i} \times\left[-1+\operatorname{ch}\left(\frac{H}{L(k l, \phi p)}\right) \times e^{-b_{i} H}\right]+\frac{1}{L(k l, \phi p)} \operatorname{sh}\left(\frac{H}{L(k l, \phi p)}\right) \times e^{-b_{i} H}\right]}{1-\left[L(k l, \phi p) \times b_{i} \times \operatorname{sh}\left(\frac{H}{L(k l, \phi p)}\right) \times e^{-b_{i} H}+\operatorname{ch}\left(\frac{H}{L(k l, \phi p)}\right)\right]}
\end{aligned}
$$

Influence of the irradiationon the optimum thickness (Hopt) by the technique of the backsurface recombination velocity

Figures 5 and 7 below show the profiles of the recombination velocity as a function of thethickness of the base for different energy flows and for different damage coefficients. 


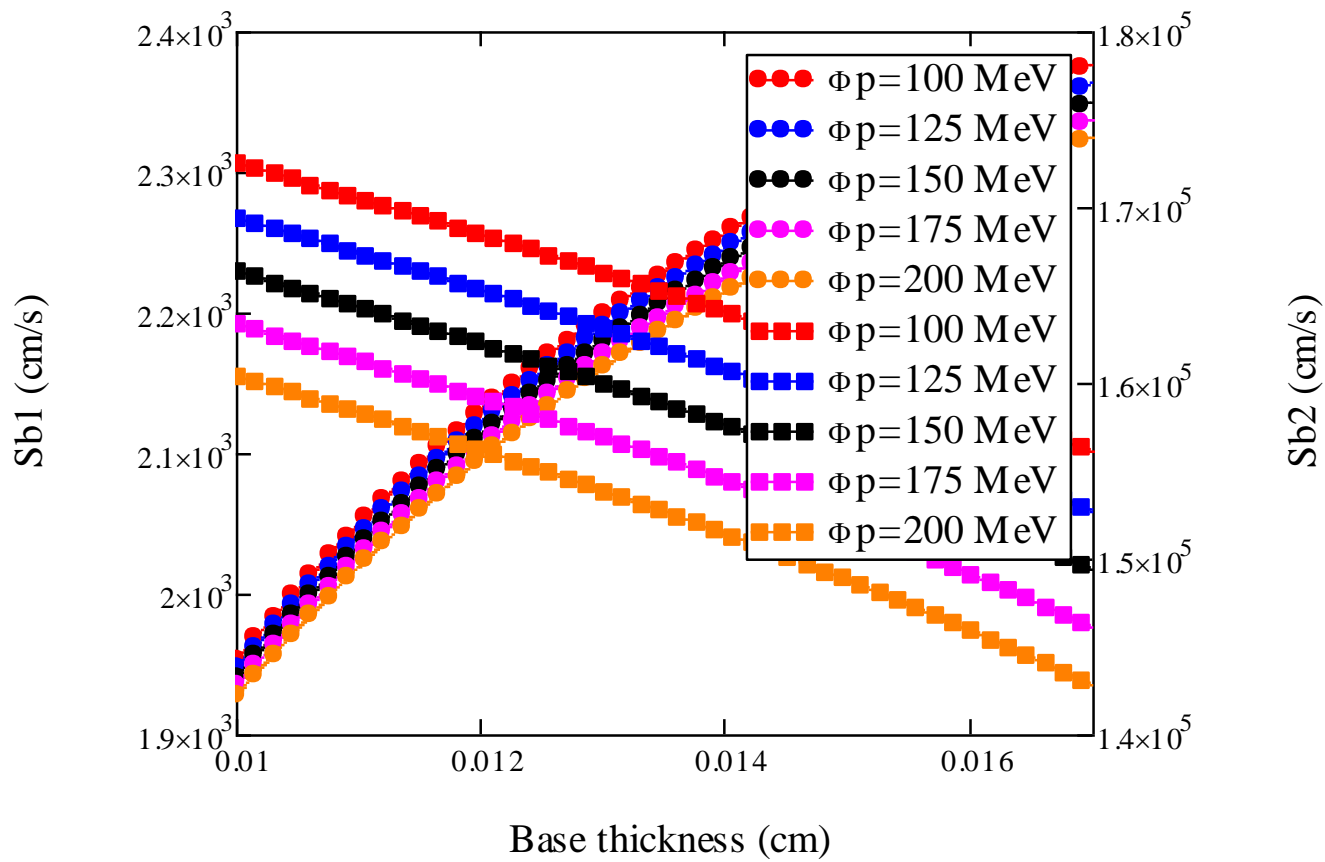

Figure 5:- Back surface recombination velocity as a function of the base thickness for different energy flows with $\mathrm{kl}=6 \mathrm{~cm}^{-2} / \mathrm{MeV}$.

Table. 1 summarizes the obtained optimum base width of the solar cell while varying the energy flows.

Tableau 1:- Hopt values for different irradiation energy flows.

\begin{tabular}{|l|l|l|l|l|l|}
\hline$\Phi p(\mathrm{MeV})$ & 100 & 125 & 150 & 175 & 200 \\
\hline $\mathrm{Hopt}(\mathrm{cm})$ & 0.0133 & 0.0129 & 0.0126 & 0.0124 & 0.0120 \\
\hline $\mathrm{Sb} 1(\mathrm{~cm} / \mathrm{s})$ & 2221.4 & 2189.3 & 2160.7 & 2128.6 & 2101.8 \\
\hline $\mathrm{Sb} 2(\mathrm{~cm} / \mathrm{s})$ & $1.6571 \times 10^{5}$ & $1.6314 \times 10^{5}$ & $1.6086 \times 10^{5}$ & $1.5829 \times 10^{5}$ & $1.5614 \times 10^{5}$ \\
\hline
\end{tabular}

Figure. 6 shows the plot of optimum base thickness versus irradiation energy flow.

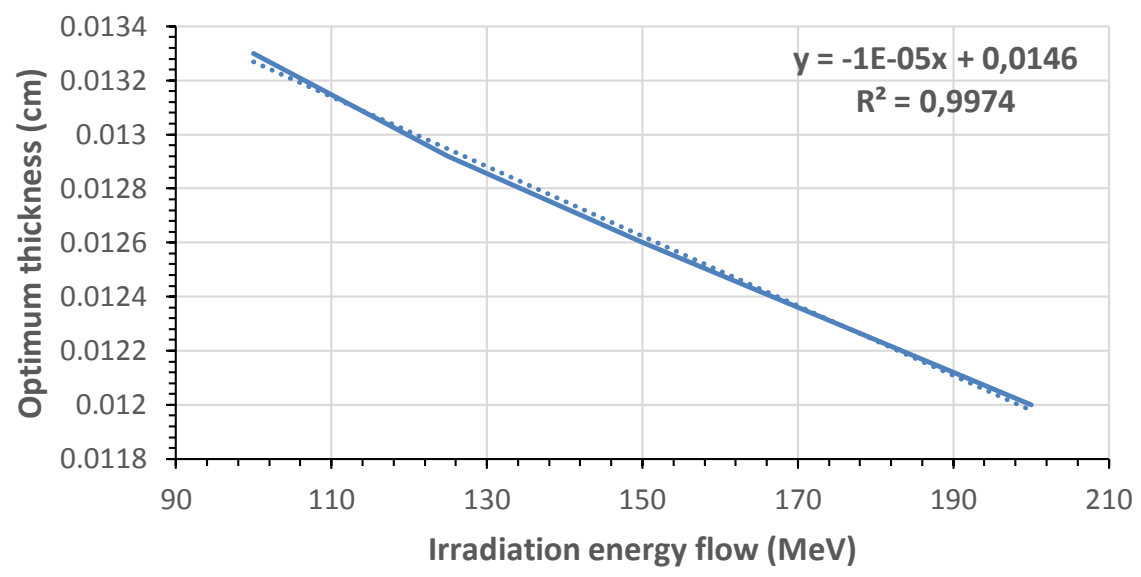

Figure 6:- Optimum thickness versus irradiation energy.

The decrease of (Hopt) optimum thickness of the base with irradiation energy is represented by a linear function. The obtained modelling relation is given as follow:

$$
\begin{aligned}
& H o p(\mathrm{~cm})=a \times \phi p+b_{(13)} \\
& a=-10^{-5} \mathrm{~cm} / \mathrm{MeV} b=0.0146 \mathrm{~cm}
\end{aligned}
$$


Figure 7 is the representation of the technique of intercept of recombination velocity curves that allows the extraction of the abscissa, which is the optimum base thickness while varying the intensity of irradiation (kl).

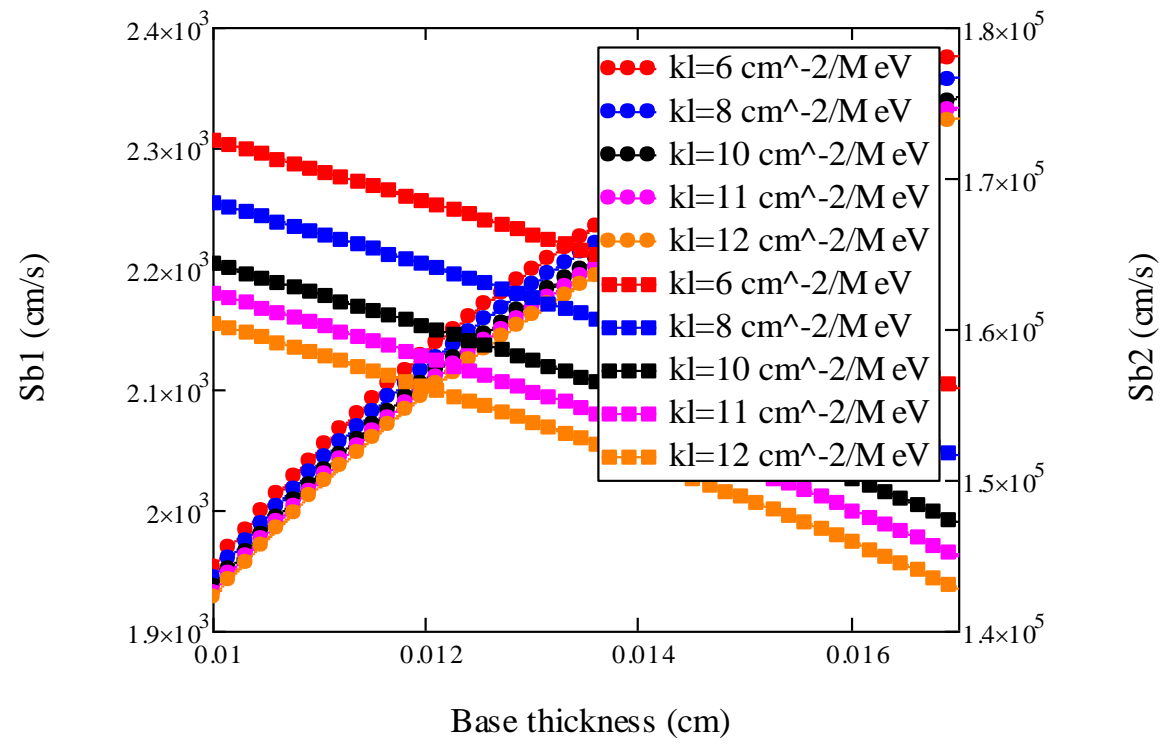

Figure 7:- Back surface recombination velocity as a function of the base thickness for differentdamage coefficient with $\phi \mathrm{p}=100 \mathrm{MeV}$.

Table 2 summarizes Hopt values based on variations in irradiation intensity (kl).

Tableau 2:- Hopt values for different damage coefficient.

\begin{tabular}{|l|l|l|l|l|l|}
\hline $\mathrm{kl}\left(\mathrm{cm}^{-2} / \mathrm{MeV}\right)$ & 6 & 8 & 10 & 11 & 12 \\
\hline $\mathrm{Hopt}(\mathrm{cm})$ & 0.0134 & 0.0129 & 0.0124 & 0.0122 & 0.0119 \\
\hline $\mathrm{Sb} 1(\mathrm{~cm} / \mathrm{s})$ & 2219.6 & 2180.4 & 2141.1 & 2117.9 & 2100 \\
\hline $\mathrm{Sb} 2(\mathrm{~cm} / \mathrm{s})$ & $1.6557 \times 10^{5}$ & $1.6243 \times 10^{5}$ & $1.5929 \times 10^{5}$ & $1.5743 \times 10^{5}$ & $1.5600 \times 10^{5}$ \\
\hline
\end{tabular}

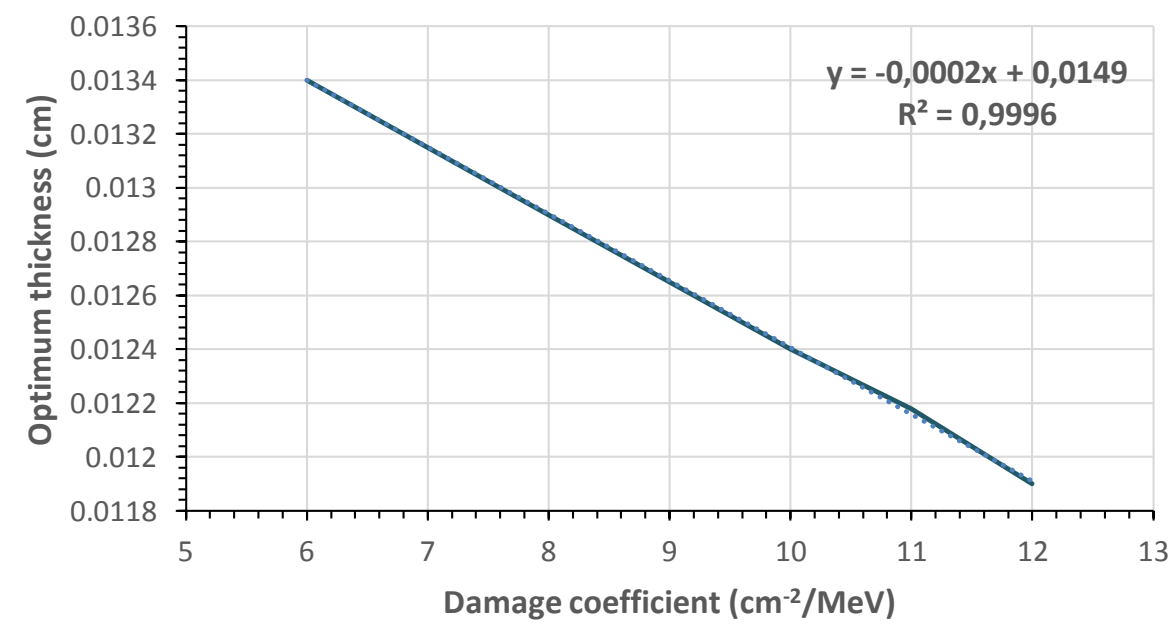

Figure 8:- Optimum thickness versus damage coefficient.

The optimum thickness is modeled as a decreasing linear function depending on the irradiation damage coefficient. The relationship is as follows:

$$
\begin{aligned}
& H o p(\mathrm{~cm})=m \times k l+n_{(14)} \\
& m=-2 \times 10^{-4} \mathrm{~cm} / \mathrm{MeV}^{n}=0.0149 \mathrm{~cm}
\end{aligned}
$$


The damages caused by the irradiation of a solar cell then lead to a reduction of the optimum thickness necessary for the production of an important photocurrent.

Knowing that the excess minority carrier recombination velocity depends on diffusion parameters $(\mathrm{D}, \mathrm{L})$ and optical parameters (monochromatic or polychromatic absorption coefficient of the material), results on the determination of optimum thickness were produced. These results take into account external factors that influence diffusion parameters (L, D).These include temperature[29], magnetic field[30], irradiation flow by charged particles[ 14], frequency of modulation[31] of optical or electrical signal, or combination of these factors[32], [33]. The conditions of manufacture of the semiconductor material through the doping rate also affect the diffusion coefficient [8].

The absorption coefficient (variable or constant) influences the recombination velocity in the rear face, also allows to produce results on the optimum thickness [34].

The different types of solar cells including the horizontal or vertical junction [35], [36] have been studied. Future investigations will take into account the 3D study model (grain boundary recombination velocity and grain size) and the combination of several external factors.

\section{Conclusion:-}

In this paper, we have proposed a method for determining the optimal thickness of the bifacial solar cell back surface illuminated and under irradiation. The expressions of the excess minority carrier in the base and the photocurrent density have been proposed. Calibration curves of the photocurrent density were plotted versus the junction recombination rate for different values of the irradiation energy ( $\phi p)$, the base thickness $\mathrm{H}$ and the damage coefficient (kl). The expressions of the excess minority carrier recombination velocity at the back surface, have been deduced and resolved graphically, to obtain the optimum thickness at intercept points of the curves. The correlation between the irradiation energy, the damage coefficient and the optimal thickness of the solar cell has been established.

\section{References:-}

1. B.E. Anspaugh (1996).GaAs Solar Cell Radiation Handbook. National Aeronautics and Space AdministrationJet Propulsion Laboratory, California Institute of Technology- Pasadena, California.

2. Cuevas, A. Luque, J. Eguren and J. del Alamo (1981). High efficiency bifacial back surface field solar cell. Solar Cells. 3, pp. 337- 340.

3. Sissoko, G., Museruka, C., Corréa, A., Gaye, I. and Ndiaye, A. L. (1996). Light Spectral Effect on Recombination Parameters of Silicon Solar Cell. World Renewable Energy Congress, Pergamon, Part III, pp.1487-1490.

4. Sissoko, G., Nanema, E., Correa, A., Biteye, P.M., Adj, M. and Ndiaye, A. L (1998). Silicon Solar cell recombination parameters determination using the illuminated I-V characteristic. Renewable Energy, Elsevier Science Ltd, 0960-1481/\#. Vol-3, pp.1848-1851.

5. Fossum, J.G. (1977) Physical Operation of Back-Surface-Field Silicon Solar Cells. IEEE Transactions on Electron Devices, 2, pp.322-325. https://doi.org/10.1109/T-ED.1977.18735

6. Joardar, K., Dondero, R.C. and Schroda, D.K. (1989). Critical Analysis of the Small-Signal Voltage-Decay Technique for Minority-Carrier Lifetime Measurement in Solar Cells. Solid State Electronics, 32, pp.479-483. https://doi.org/10.1016/0038-1101(89)90030-0

7. G. Sissoko, E. Nanéma, A. Corréa, M.Adj, A. L. Ndiaye, M. N. Diarra(1998). Recombination parameters measurement in double sided surface field solar cell. Renewable Energy, vol-3, pp.1856-59.-Elsevier Science Ltd, 0960-1481/98/\#.

8. Masse Samba Diop, Hamet Yoro Ba, Ndeye Thiam, Ibrahima Diatta, Youssou Traore, Mamadou Lamine Ba, El Hadji Sow, Oulymata Mballo, Grégoire Sissoko (2019). Surface Recombination Concept as Applied to Determinate Silicon Solar Cell Base Optimum Thickness with Doping Level Effect. World Journal of Condensed Matter Physics, 9, pp.102-111. https://www.scirp.org/journal/wjcmp

9. Luque, J. M. Luiz, A. Cuevas, J. Eguren and J. M. Gomez-August(1978). Double-Sided solar cells to improve static concentration, Proc. $1^{\text {st }}$. European Photovoltaic Solar Energy Conference, pp.269-277.

10. Nam, L., Rodot, M., Nijs, J., Ghannam, M. and Coppye, J. (1992) Réponse spectrale de photopiles de haut rendement au silicium multicristalline. Journal de Physique III, EDP Sciences, 2, pp.1305-1316. https://doi.org/10.1051/jp3:1992108 
11. J. Del Alamo, J. Eguren and A. Luque (1980). Operating limits of Al-Alloyed high-low junction for BSF solar cells. Solid-States-Electronics Vol. 24, pp.415- 420.

12. Daniel L Meier, Jeong-Mo Hwang, Rabert B. Campbell (1988). The effect of doping density and injection level on minority carrier lifetime as applied to bifacial dendritic Web silicon solar cell. IEEE Transactions on electron devices, vol. ED-3, No. 1, pp.70-79.

13. M. A. Ould El Moujtaba, M. Ndiaye, A. Diao, M. Thiame, I. F. Barro and G. Sissoko (2012). Theoretical Study of the Influence of Irradiation on a Silicon Solar Cell under Multispectral Illumination. Res. J. Appl. Sci. Eng. Technol., 4(23), pp.5068-5073.

14. Mamadou Lamine Ba, Ndeye Thiam, Moustapha Thiame, Youssou Traore, Masse Samba Diop, Mamour Ba, Cheikh Tidiane Sarr, Mamadou Wade and Gregoire Sissoko(2019). Base thickness optimization of a $\left(n^{+}-p-p^{+}\right)$ silicon solar cell in static mode under irradiation of charged particles Journal of Electromagnetic Analysis and Applications, 2019, 11, 173-185 https://www.scirp.org/journal/jemaa

15. R. Car, A. Selloni, J.F. Janak and S.T. Pantelides (1983). The properties of crystalline silicon under Laser irradiation. Physica 117B and 118B,pp. 1007-1009.

16. Y. Bester, D. Ritter, G. Bahia, S. Cohen, J. Sparkling, (1995). Method measurement of the minority carrier mobility in the base of heterojunction bipolar transistor using a magnetotransport method. App. Phys. Lett. Vol.67 (13), pp.1883-1884

17. Kunst, M. and Sanders, A (1992). Transport of Excess Carriers in Silicon Wafers. Semiconductor Science and Technology, 7, 51-59. https://doi.org/10.1088/0268-1242/7/1/009

18. K. Misiakos and F.A. Lindholm (1987). Minority carrier accumulation at the base edge of a junction space charge region under short circuit condition. Solid States. Electron, 30. pp.755-758.

19. Mandelis (1989).Coupled ac. Photocurrent and photothermal reflectance response theory of semiconducting p-n junctions J. Appl. Phys. Vol.66 (11), pp.5572-5583.

20. Donolato, (1999) Effective Diffusion Length of Multicrystalline Solar Cells.Solid State Phenomena Vols. 6768, pp.75-80.

21. J.Dugas (1994).3D modelling of reverse cell made with improved multicrytalline silicon wafers,Solar Energy Materials and Solar Cells, pp 71-88, 32/

22. Attoumane Mamadou Moustapha Kosso, Moustapha Thiame, Youssou Traore, Ibrahima Diatta, Mor Ndiaye, Lemrabott Habiboullah, Ibrahima LY, Grégoire SISSOKO. (2018) 3D Study of a Silicon Solar Cell under Constant Monochromatic Illumination: Influence of Both, Temperature and Magnetic Field, Journal of Scientific and Engineering Research, 5(7), pp.259-269.

23. Diallo. H.L, Seïdou. A. Maiga, Wereme. A and Sissoko G (2008). New Approach of Both Junction and Back Surface Recombination Velocities in a 3D Modelling Study of a Polycrystalline Silicon Solar Cell. The European Physical Journal Applied Physics, 42, pp.203-211. https://doi.org/10.1051/epjap:2008085

24. W. Rosenzweig (1962). Diffusion length measurement by mean of ionization radiation. Bell Syst. Tech. J. Vol. 41, pp. 1573- 1588 .

25. Rose, B.H. and Weaver, H.T. (1983). Determination of Effective Surface Recombination Velocity and Minority-Carrier Lifetime in High-Efficiency Si Solar Cells. Journal of Applied Physics, 54, pp.238-247. https://doi.org/10.1063/1.331693

26. Furlan, J. and Amon, S. (1985). Approximation of the Carrier Generation Rate in Illuminated Silicon. Solid State Electronics, 28, pp.1241-1243. https://doi.org/10.1016/0038-1101(85)90048-6

27. Y. L. B. Bocande, A. Correa, I. Gaye, M. L. Sow and G. Sissoko (1994). Bulk and surfaces parameters determination in high efficiency Si solar cells. Renewable Energy, vol 5, part III, pp. 1698-1700, Pergamon, 0960-1481/94\$ $700+0.00$.

28. Corréa, I. Gaye, B. Ba, A. L. Ndiaye, and G. Sissoko (1994). Solar cells parameters determination by constant illumination induced transient voltage decay method. Renewable Energy, Vol 5, part I, pp.166-168, -Pergamon, 0960-1481/94\$ $700+0.00$.

29. Y. Traore, N. Thiam, M. Thiame, M. L. Ba, M. S. Diouf and G. Sissoko (2019). AC Recombination Velocity in the Back Surface of a Lamella Silicon Solar Cell under Temperature.Journal of Modern Physics, vol. 10, pp. 1235-1246.

30. Faye. D, Gueye. S, Ndiaye. M, Ba. M, Diatta. I, Traore. Y, Diop. M, Diop. G, Diao. A, and Sissoko. G (2020). Lamella Silicon Solar Cell under Both Temperature and Magnetic Field: Width Optimum Determination. Journal of Electromagnetic Analysis and Applications, 12, 43-55. doi: $10.4236 /$ jemaa.2020.124005 
31. M. Gueye, H. L. Diallo, A. Kosso, M. Moustapha, Y. Traore, I. Diatta et G. Sissoko(2018). «Ac Recombination Velocity in a Lamella Silicon Solar Cell. World Journal of Condensed Matter Physics, vol. 8, pp. 185196,http://www.scirp.org/journal/wjcmp.

32. Maimouna Mint ELY, Ndeye Thiam, Mor Ndiaye, Youssou Traore, Richard Mane, El hadji Sow, Oulimata Mballo, Masse Samba Dieng, Cheikh Tidiane Sarr, Ibrahima Ly, Gregoire Sissoko (2020). Surface recombination velocity concept as applied to determinate back surface illuminated silicon solar cell base optimum thickness, under temperature and external magnetic field effects. Journal of Scientific and Engineering Research, 7(2), pp.69-77, www.jsaer.com

33. Nouh Mohamed Moctar Ould Mohamed, Ousmane Sow, Sega Gueye, Youssou Traore, Ibrahima Diatta, Amary Thiam, Mamour Amadou Ba, Richard Mane, Ibrahima Ly, Gregoire Sissoko (2019). Influence of Both Magnetic Field and Temperature on Silicon Solar Cell Base Optimum Thickness Determination. Journal of Modern Physics, 10, pp.1596-1605 https://www.scirp.org/journal/jmp

34. Meimouna Mint Sidi Dede, Mor Ndiaye, Sega Gueye, Mamadou Lamine Ba, Ibrahima Diatta, Marcel Sitor Diouf, El Hadj Sow, Amadou Mamour Ba, Massamba Diop, And Gregoire Sissoko (2020). Optimum base thickness determination technique as applied to $\mathrm{n} / \mathrm{p} / \mathrm{p}+$ silicon solar cell under short wavelengths monochromatic illuminationInternational Journal of Innovation and Applied Studies ISSN 2028-9324 Vol. 29 No. 3 Jun. 2020, pp. 576-586 @ 2020 Innovative Space of Scientific Research Journals http://www.ijias.issrjournals.org/

35. Omar Dia, Mohamed Abderrahim Ould El Moujtaba, Sega Gueye, Mamadou Lamine Ba, Ibrahima Diatta, Gora Diop, Marcel Sitor Diouf And Gregoire Sissoko (2020). Optimum thickness determination technique as applied to a series verticaljunction silicon solar cell under polychromatic illumination: effect of irradiation. International Journal Of Advanced Research. 8(05), 616-626. (IJAR) ISSN 2320-5407 http://dx.doi.org/10.21474/IJAR01/10967

36. G. Diop, H. Y. Ba, N. Thiame, Y. Traore, B. Dione, A. M. Ba, P. Diop, M. S. Diop, O. Mballo et G. Sissoko (2019). Base Thickness Optimization of a Vertical Series Junction Silicon Solar Cell Under Magnetic Field by The Concept of Back Surface Recombination Velocity of Minority Carrier.Journal of Engineering and Applied Sciences, vol. 14, pp. 4078-4085, www.arpnjournals.com. 